The 410 cases which the author has studied at Westminster Hospital are split up into the various groups in Tables 1 to 5 , but to present the threeyear survival rates in figures with two decimals (for example 12 cases $=16.66$ per cent.) seems futile. To present age incidence both in the form of a table and as a graph is not permitted by any medical journal, but it is done here on pages 30 and $3 \mathbf{r}$.

Chapters 5 to 10 are taken up by descriptions of the tumours: follicular lymphoma, lymphosarcoma, reticular lymphoma, Hodgkin's disease, reticulum cell sarcoma and anaplastic sarcoma. Dr. Lumb regards lymphosarcoma and lymphatic leukaemia as really much the same disease entity and this opinion will be shared by many.

Chapter I I deals with problems of diagnosis. It is astonishing to find no mention of the Haematoxylin and van Gieson's method in paragraphs dealing with staining. After all it is probably the best to show fibrosis, which is such a feature in many cases of Hodgkin's disease. In the classification of the leukaemias, discussed in the section of the differential diagnosis, " chronic monocytic leukaemia' is mentioned, though no case of ' monocytic leukaemia' has ever survived more than two or three months and it is even doubtful if such an entity really exists. The extremely rare basophilic leukaemia is mentioned, but the author does not appear to have heard of erythraemic myelosis (Di. Guglielmo's disease). More than 60 photographs illustrate other malignant and granulomatous lesions such as Gaucher's disease, Brucellosis, torulosis, histoplasmosis and Boeck's sarcoidosis, but they do not seem really within the scope of the work.

The effects of treatment on primary tumours of lymphoid tissue are discussed in a very short chapter, but the effects of ACTH or cortisone are not even mentioned.

The details of 19 cases used to illustrate the features of the morbid states described are given in the final chapter.

The book is lavishly illustrated and well produced. It is irritating to find the same cell in three photographs (Figs. I, 8; I, I IA and 8, I 8) and some of the pictures are not really helpful, but most are of good quality and some are really excellent. The tables vary in value, but Table $I I$ is an example of how not to make a table. Under ten headings, material observed appears only in four columns, leaving six empty spaces!

The style is conventional, but there are annoying mannerisms. Cells do not occur in sheets. This would indicate a two-dimensional spread only. They really occur in masses.

A lot of material has provided the basis for this book, but one gains the impression that though the main headings have been rightly selected, more attention to details and more care in the preparation of the manuscript might have produced a much more worthwhile treatise.

E.N.

\section{CLINICAL BACTERIOLOGY}

By E. JoAN Stokes, M.B., B.S., M.R.C.P., M.R.C.S. Pp. vii +288 , with 25 illustrations. London: Edward Arnold, Ltd. 1955. 20s.

A well produced, usefully tabulated and diagrammed book, compact and modestly priced.

The subject is well covered, all commonly and not a few uncommonly needed techniques being included.

The methods are those of one particular laboratory; therefore not everyone will agree with some of the finer points of the methods described. For routine work many will regard some of the identification techniques as too detailed and time consuming, but no one can quarrel with them as an ideal to be aimed at when time and cost are no object.

Junior staff will find this book a good bench companion and a reference more easily and rapidly handled than the larger works. In addition it forms, with its bibliography, an adequate framework upon which to build when studying for the postgraduate diplomas in pathology.

The general clinician and surgeon will find much of use and value in the chapters on antibacterial drugs and Hospital Epidemiology; this latter chapter should also be read by those about to qualify as it will save them much trouble later on.

For those who wish to gain a rapid insight intes the scope of modern bacteriological practice as of operates in Britain today, I can recommend ne better book.

\section{GYNAECOLOGY}

By Douglas H. MacLeod, M.S., F.R.C.P., F.R.C.S., F.R.C.O.G. and-Charles D. READ, M.B., F.R.C.S., F.R.A.C.S. Fifth Edition. Pp. 864; with 55I illustrations, 27 in colour. London: J. \& A. Churchill Ltd. I955. 80s.

This book has long been awaited. For the first time it is now possible to prepare for the higher examinations in gynaecology without having to have recourse to an American textbook.

The authors, who are probably two of the most successful and skilful gynaecological surgeons in London today, have combined their experience to produce a work that is practical in the extreme, and $\mathrm{O}$ yet reveals the deepest perusal of the academic literature of the subject. It is eminently readable.

The chapter on anatomy by Mr. Snyder surely does fulfil the hopes of the editors that it is accept- $N$ able to the anatomists as well as the gynaecologists. What is more, it is easier to follow than most anatomical works.

The chapter on physiology makes clear some of the confusing modern knowledge of the $\operatorname{sex} 0$ hormones; but could perhaps have been a little $\widetilde{\Phi}$ fuller.

A textbook of this nature meets its severest test, possibly, when it comes to discuss ovarian tumours. The classification given by the authors is reasonable, and the several chapters devoted to the pathology 
of ovarian tumours are lucid and in spite of many references to other sources, steer a clearly understood path through the maze that traps so many postgraduate students.

The section on gynaecological operations could only have been written by men who are as good technical masters as the authors are; and who have been teaching surgery for years.

Use has been made of the drawings of Victor Bonney, and since both authors were pupils of the great Bonney, the operative technique described derives from his, but there are many modern advances added.

The book is detailed in the extreme. It was a pleasure for instance to find more than one page devoted to true hydatid tumours, when the reviewer had unexpectedly found one at laparotomy. Yet the book is certainly not encumbered with unnecessary reading material.

The reproduction of the diagrams is, in the main, excellent, although perhaps a little more pruning of some of the old illustrations might have been carried out because they do add to the price; yet the work is remarkable value, and is probably now a 'must' for the M.R.C.O.G.

But why did the publishers produce such a dull dust jacket for such a brilliant book ?

E.E.P.

\section{CLINICAL ASPECTS OF THE AUTONOMIC NERVOUS SYSTEM}

By L. A. Gillilan, Ph.D., M.D. Pp. xii +316 , with 42 illustrations. London: J. \& A. Churchill Ltd. 1955. 45s.

Professor Gillilan has given us a most interesting account of the anatomy of the autonomic nervous system. He has demonstrated a number of important consequences arising from the anatomy of this part of the nervous system. The presentation and printing are excellent and it is easy to look up the neuro-anatomy of any particular region. A wide range of references is given.

It is surprising perhaps that some rather fundamental work has been omitted from the text, such as Lewis's work on referred pain, and the work of Guttmann and Whitteridge on afferent pathways from the bladder, or the work of Harris and others on the hypothalamic control of some pituitary mechanisms. One finds, too, some feeling of confusion in the use of the works 'sympathetic' and 'para-sympathetic,' although the author does himself draw attention to some paradoxes involved in the ordinary use of these terms. There are instances in which perhaps the explanations given of clinical phenomena are a little over-simplified. The view is expressed that there is a vaso-constrictor sympathetic inflow and a vaso-dilator para-sympathetic inflow, and this view of the control of the peripheral blood vessels is, if correctly interpreted by the reviewer, most unorthodox.

This book will be of considerable interest to most medical men and in particular to those who have special interest in the autonomic nervous system. $\stackrel{\mathbb{D}}{\mathcal{Q}}$

K.E.C.

\section{MAN IN A COLD ENVIRONMENT}

By Alan C. Burton, Ph.D. and Otto G. Edholm, 을 M.B., B.S. Pp. xiv +273 , with 75 illustrations. London: Edward Arnold Ltd. 1955. 3os."

Over the past quarter of a century a great deal of knowledge has been accumulating on the physio- logical responses of man to his environment. Little. of this information has so far reached the standard $\vec{A}$ textbooks and most of that which has done so is $\vec{\rho}$ made up of rather dogmatic half-truths. The time was therefore ripe for a more detailed account of some aspects of body temperature regulation in man. The authors of this book have set themselves the $\omega$ difficult task of reviewing a very wide field of work. They have rightly used a considerable space in $N$ reviewing and describing the physical principles $\omega$ which must be common knowledge to anyone who aspires to intelligent research in temperature regulation. Besides this, the physics of the designo of insulated clothing are discussed and this section? is presented in easily readable form. The remainderc of the book, which deals with the physiological responses to cold, is well written and contains a good $\overrightarrow{.}$ selection from the available literature. There age also within the book some very thought-provokikg philosophical discussions. The authors have dowe a good job in selecting the salient features from vast mass of literature and this book, because of the way in which the principles underlying temperature regulating mechanisms are discussed, should form part of the armament of anyone interested in body temperature regulation.

K.E.C.

\section{NEUROLOGY}

By S. A. KINNIER Wilson, M.A., M.D., D.Sc., $\frac{\partial}{3}$ F.R.C.P. Edited by A. Ninian BruCE, F.R.C.P., D.Sc., M.D., F.R.S. Second edition. Three Vols. Pp. xii, viii and viii $+2060+99$, with 279 . illustrations. London: Butterworth \& Co., Ltd. 1954. £10 ros. the set or $£ 3$ ros. per vol.

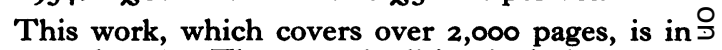
three volumes. The second edition includes a new $D$ chapter on aphasia, apraxia and agnosia, and the chapter on neurosyphilis has been modified. The N general character of the first edition has been? undisturbed.

This is in many ways a remarkable book. The N historical field it covers is enormous; indeed, the $\omega$ text bristles with so many references as to become

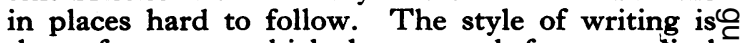
that of an age which has passed from medical $\mathbb{\infty}$ literature and the pages are larded with an abundance? of latin tags. The approach to the subject, too, is ${ }^{7}$ somewhat dated, belonging to an era when toxins in ${ }_{0}$ various guises supposedly accounted for most $\stackrel{\mathbb{\Phi}}{?}$ features of disease not clearly accountable by other $\frac{?}{\mathscr{Q}}$ 